\title{
Derivatives of 1,2,4-Triazole-3,4-Disubstituted Based on Aminoacids with Potential Biological Activity
}

\section{CORINA CHEPTEA ${ }^{1 *}$, VALERIU SUNEL ${ }^{2}$, CEZARINA MOROSANU $^{3}$, DANA ORTANSA DOROHOI ${ }^{3}$}

${ }^{1}$ Grigore T. Popa University of Medicine and Pharmacy of Iasi, Faculty of Medical Bioengineering, Department of Biomedical Sciences, 9-13, M. Kogalniceanu Str., 700454, Iasi, Romania;

${ }^{2}$ Al. I. Cuza University of Iasi, Faculty of Chemistry, 11 Carol I Blvd, 700506, Iasi, Romania;

${ }^{3}$ Al. I. Cuza University of Iasi, Faculty of Physics, 11 Carol I Blvd, 700506, Iasi, Romania

\begin{abstract}
In order to obtain new substances with potential biological activity dipeptide derivatives from p-aminobenzoyl-phenylglycine and p-aminobenzoyl-phenylalanine were grafted on 1,2,4-triazolic heterocycle. The new synthesized compounds belong to the group of antimetabolites, group used in medicine for treating malignant tumors. Also, it is possible to study the correlation between chemical structure and biological activity of the new compounds.
\end{abstract}

Keywords: dipeptides derived from p-aminobenzoyl-phenylglycine and p-aminobenzoyl-phenylalanine, 1,2,4-triazole-3,4-disubstituted heterocyclic compounds, biological activity

\section{Introduction}

The malignant tumours are considered serious health problems today. The current trend in chemotherapy of malignant tumours is characterized by using the treatments with the compounds that manifests as antimetabolites. Among all the current therapeutic methods, chemotherapy remains an important option for cancer treatment: inhibition of the characteristic proliferation pathways of cancer cells constitutes an effective strategy to fight this pathology.

There are studies regarding the synthesis of a number of $\alpha$-amino acid derivatives, some of them having a cytostatic activity, exerted by the antagonist effect of the aminic acid or dipeptide, respectively [1-10].

The structure of the new synthesized substances contains the peptide fragment, the indazole ring, and the 1,2,4-triazole heterocycle. The triazole derivatives are important due their antimicrobial [1114], anti-inflammatory [15,16], antifungal [17-19], analgesic [20-22], cardio protective [23], antitumor [15] actions.

Indazole and its derivatives present different pharmacological properties: antihistaminic [24], antiviral [25], antimicrobial [26, 27], anti-inflammatory [28], cytostatic [29-31], analgesic-antipyretic [32], anti-HIV [33], antifungal [34], antagonists of glucocorticoid receptor [35].

Peptide fragment shows interesting biological properties [4, 10, 36-38].

Phenylglycine and phenylalanine as well as their acylated derivatives with the substituted benzoyl fragment in para, taking part in the metabolism of living organisms, reduce the toxicity of some medicinal products, also facilitating their access to the cellular level [4, 16, 39-46].

In order to obtain derivatives with reduced toxicity and high therapeutic action, a series of syntheses were performed by replacing the hydrogen of the amino group in the molecule of the $\mathrm{N}$-(paminobenzoyl)-D,L-phenylglycine and $\mathrm{N}$-(p-aminobenzoyl)-L-phenylalanine with the 5-mercapto1,2,4-triazole-3,4-disubstituted heterocyclic system.

D,L- phenylglycine and L-phenylalanine derivatives were synthesized by V. Sunel and collaborators, compounds which have been shown to be active against various pathogens $[48,49]$.

The study of the mutual influence of the three components which are present in the same molecule as well as their contribution to the global biological activity of the substance it is interesting.

\footnotetext{
*email: coricheptea@yahoo.com
} 
The aim of this research was to establish some physico-chemical properties of the synthesized 1,2,4-triazole-3,4-disubstituted based on aminoacids derivatives having in view their potential biological activity.

\section{Materials and methods}

The synthesis of the novel combinations was accomplished by reacting 1,2,4-triazole derivatives with $\mathrm{N}$-(p-aminobenzoyl)-D,L-phenylglycine and $\mathrm{N}$-(p-aminobenzoyl)-L-phenylalanine, respectively.

The triazole derivatives were obtained by cyclization in basic medium of acyl-thiosemicarbazides, prepared in turn by condensation of isothiocyanates with 5-nitroindazole-1-yl-acetic acid hydrazide [27].

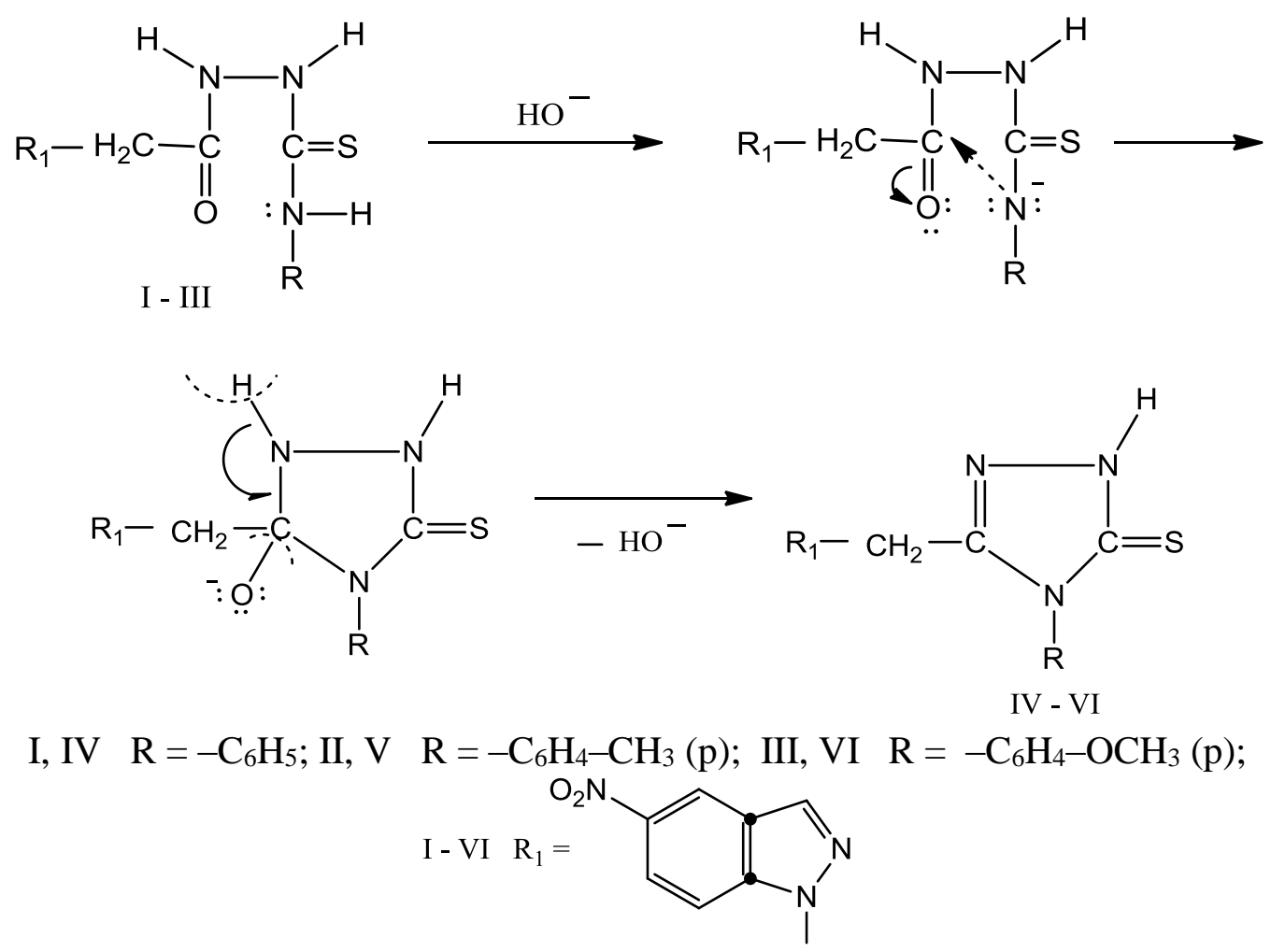

Due to the presence in their molecule of thioamide group $\|$, 5-thio-1,2,4-triazoles-3,4disubstitution presents the phenomenon of double reactivity, in the sense that in depending on the nature of the reactant and the working conditions, it reacts as if it had either the thionic structure IV-VI (A) or the thiolic structure IV-VI (B). This property explains the existence of the reaction center at the sulphur atom at position 5 of the triazolic heterocycle.<smiles>[R]Cc1n[nH]c(=S)n1[R]</smiles>

A<smiles>[R]Cc1nnc(S)n1[R]</smiles>

IV - VI

The mercapto triazole in SH form reacts with the ethyl ester of bromoacetic acid, in basic medium forming S-derivatives VII-IX (Scheme 1) 


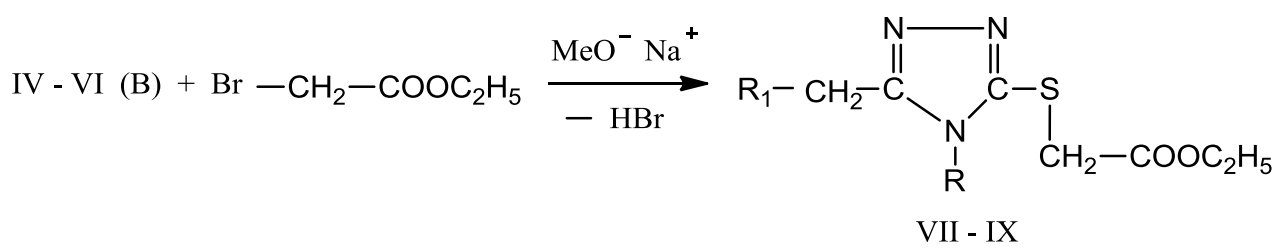

IV, VII $\mathrm{R}=-\mathrm{C}_{6} \mathrm{H}_{5} ; \quad \mathrm{V}, \mathrm{VIII} \quad \mathrm{R}=-\mathrm{C}_{6} \mathrm{H}_{4}-\mathrm{CH}_{3}(\mathrm{p}) ; \quad \mathrm{VI}, \mathrm{IX} \quad \mathrm{R}=-\mathrm{C}_{6} \mathrm{H}_{4}-\mathrm{OCH}_{3}(\mathrm{p})$;<smiles>[R17]N=[N+]([O-])c1ccc2c(cnn2C)c1</smiles>

Scheme 1. The synthesis of 3-[(5'-Nitro-1H-indazol-1'-yl)-methyl]-4-aryl-1, 2, 4-triazole-5thioacetic esters (VII-IX)

The reaction system was heated to $65-70^{\circ} \mathrm{C}$ for $4 \mathrm{~h}$ and the yields of the finished products was comprised between $71-85 \%$. The purification was performed from ethanol and the structure of the obtained substances was investigated by elemental and spectral analysis (FT-IR, ${ }^{1} \mathrm{H}-\mathrm{NMR}$ ).

A characteristic band of the $\mathrm{C}=\mathrm{O}$ ester group at 1703-1737 $\mathrm{cm}^{-1}$, and the specific band for the $\mathrm{C}$ $\mathrm{S}$ group at 586-690 $\mathrm{cm}^{-1}$ appear in IR spectra of the studied compounds. The vibrations of the $\mathrm{C}=\mathrm{N}$ bond were identified at $1623-1677 \mathrm{~cm}^{-1}$.

The bands characteristic of the symmetrical and asymmetric vibrations of the $\mathrm{NO}_{2}$ group appear in all IR spectra both at $1312-1337 \mathrm{~cm}^{-1}$ and at $1518-1598 \mathrm{~cm}^{-1}$, respectively, and the bands corresponding to the p-disubstituted benzene nucleus appears at $749-834 \mathrm{~cm}^{-1}$.

The values of the chemical displacements and the intense peak of the ${ }^{1} \mathrm{H}-\mathrm{NMR}$ spectra are fully consistent with the type and number of protons in the compounds VII-IX. In the aliphatic zone, the protons of the methyl group are identified at $\delta=1.19-1.29 \mathrm{ppm}$ and for compounds VIII and IX, the protons of the methyl group linked to the phenyl moiety appears at $2.34 \mathrm{ppm}, 3.84 \mathrm{ppm}$, respectively.

The protons of the $\mathrm{CH}_{2}$ group from $-\mathrm{COOCH}_{2} \mathrm{CH}_{3}$ are identified at 4.08-4.19 ppm while the signal of the protons of the $\mathrm{CH}_{2}$ group bound to the nitrogen atom from position 1 of the indazole nucleus, appears at 5.31-5.77 ppm in NMR spectra. The aromatic protons appear as singlets at 8.30-8.44 ppm and doubles at 7.11-7.89 and 8.86-8.89 ppm, respectively.

In order to graft the peptide fragment onto the triazole nucleus, compounds VII-IX reacted with N(p-aminobenzoyl)-D,L-phenylglycine and N-(p-aminobenzoyl)-L-phenylalanine.

It is known that the aminolysis reaction of the esters depends on both the reactivity of the amine and that of the ester. The amine group involved in the syntheses, presented in the paper, has a lower basicity, hence a lower reactivity, given its role as a nucleophilic agent. The low reactivity of the amine group is compensated by the high reactivity of the thioacetic ester.

The condensation reaction between ethyl thioacetates (VII-IX) and aminobenzoyl-D,Lphenylglycine and aminobenzoyl-L-phenylalanine occurred in anhydrous dioxane, at $85-90^{\circ} \mathrm{C}$, in excess of acyl-amino acid, for 5 hours. 2 Moles of acyl amino acid was used per mole of ester [50]. Pure crystalline products (X-XV) (Scheme 2) which melt at fixed temperatures were obtained, after precipitation and purification.

The composition and structure of the compounds (X-XV) were determined by chemical and spectral analysis (FT-IR, ${ }^{1} \mathrm{H}-\mathrm{NMR}$ ).

Characteristic bands to the NH group appear in IR spectra at 2822-3408 $\mathrm{cm}^{-1}$.

Intense bands appear between $1613-1689 \mathrm{~cm}^{-1}$ characteristic to the carbonyl amide group and also the bands at $1335-1342 \mathrm{~cm}^{-1}$, as well as at $1516-1582 \mathrm{~cm}^{-1}$ corresponding to the symmetrical and 
asymmetric vibrations of $\mathrm{NO}_{2}$ group appear in all IR spectra. The compounds XII and XV still have a band at $1107 \mathrm{~cm}^{-1}$, respectively at $1109 \mathrm{~cm}^{-1}$ attributed to the methoxy group.

The absorption band of the $\mathrm{S}-\mathrm{CH}_{2}$ group, at $746-790 \mathrm{~cm}^{-1}$, an intense band at $815-897 \mathrm{~cm}^{-1}$ specific for the p-disubstituted benzene nucleus, as well as a broadband specific to the -COOH group in the domain 3242-3286 $\mathrm{cm}^{-1}$ were identified in IR spectra of all studied compounds.

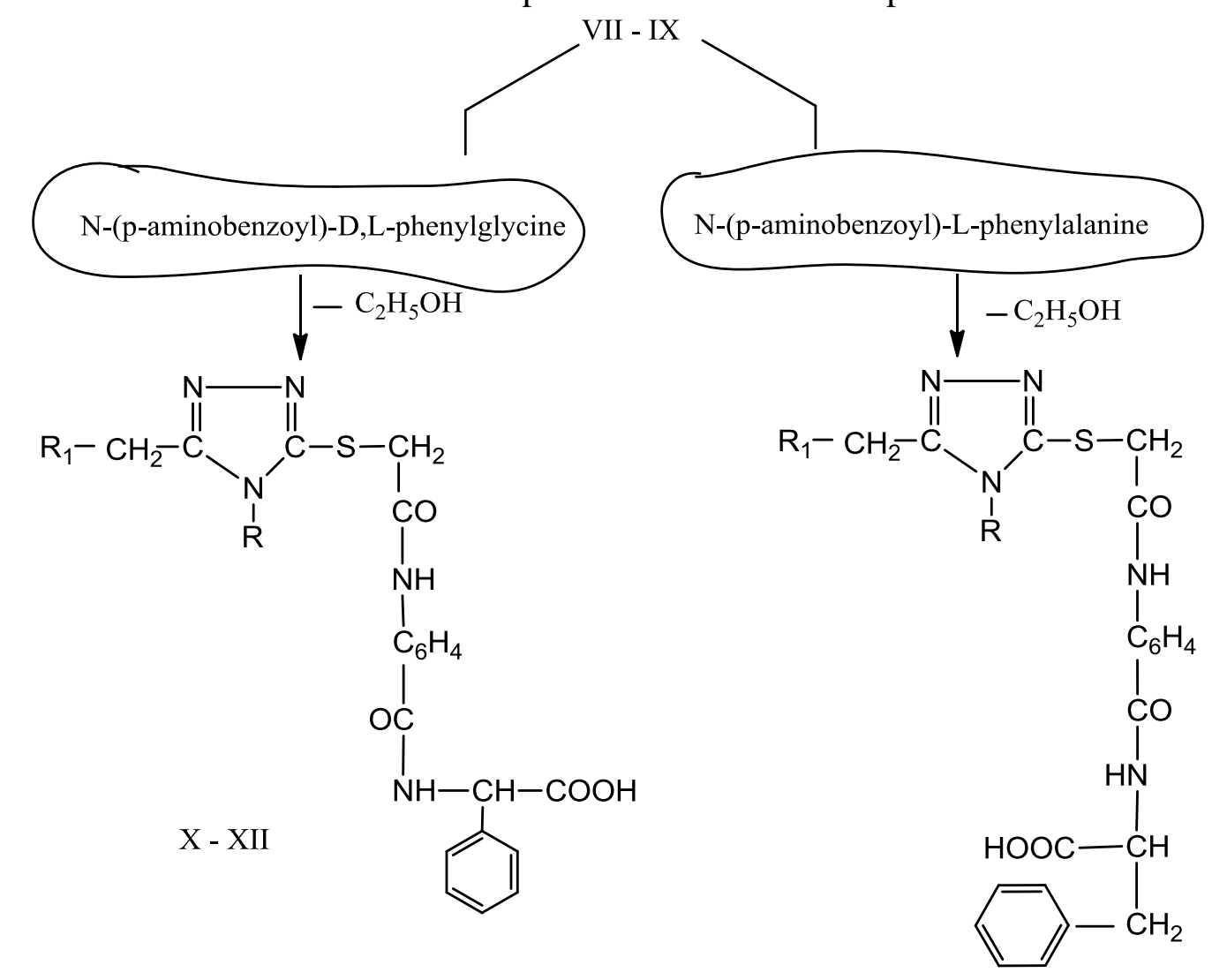

XIII - XV

$\mathrm{X}, \mathrm{XIII} \mathrm{R}=-\mathrm{C}_{6} \mathrm{H}_{5} ; \mathrm{XI}, \mathrm{XIV} \mathrm{R}=-\mathrm{C}_{6} \mathrm{H}_{4}-\mathrm{CH}_{3}(\mathrm{p}) ; \mathrm{XII}, \mathrm{XV} \mathrm{R}=-\mathrm{C}_{6} \mathrm{H}_{4}-\mathrm{OCH}_{3}(\mathrm{p})$<smiles>[Y][W]=[N+]([O-])c1ccc2c(cnn2C)c1</smiles>

Scheme 2. The synthesis of 3-[(5'-nitro-1H-indazole-1'-yl)-methyl]-4-aryl-1,2,4-triazole-5-( $\alpha$ thioacetyl peptides $(\mathrm{X}-\mathrm{XV})$

Signals at 2.87-3.30 ppm attributed to the protons of the $\mathrm{CH}_{2}$ group next to the $\mathrm{CO}$ bond to $\mathrm{NH}$ group from $\mathrm{N}$-(p-aminobenzoyl)-D,L-phenylglicine and $\mathrm{N}$-(p-aminobenzoyl)-L-phenylalanine respectively and at 4.5-5.97 ppm to the proton of the $\mathrm{CH}$ group appear in NMR spectra of all compounds X-XV.

The aromatic protons are also found at 6.30-7.28, 7.43-8.39 ppm and 8.48-9.12 ppm in NMR spectra.

In NMR spectra of compounds XI and XIV, the protons corresponding to the methyl group appear as a single at 2.11-2.43 ppm, while, the signal recorded in the range 3.90-3.94 ppm is assigned to the protons of the $\mathrm{OCH}_{3}$ group. The $\mathrm{NH}$ amide groups are identified by peaks that appear as a single at 7.80-8.06 ppm and a doublet at 8.15-8.87 ppm. The proton of the carboxylic group appears in domain 12.20-12.95 ppm which shows that the graft reaction of dipeptides on the triazole nucleus took place. 
The structures X-XV were supposed to a quantum chemical analysis with Spartan 14 and some electro-optical parameters were computed after the geometry optimization [51]. Some dependences can be established for these compounds.

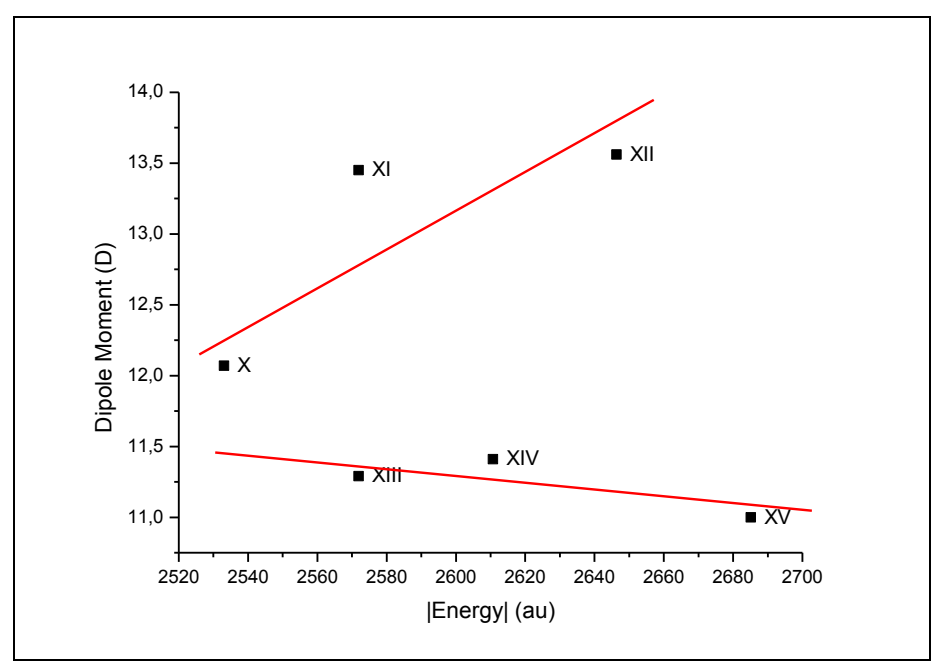

Figure 1. Dipole moment vs. modulus of the molecular energy

There is a tendency (Figure 1) to increase the electric dipole moment in the ground state of the molecules with the increase in the modulus of the formation energy in the case of compounds X-XII and a tendency to slowly decrease in the modulus of the molecular energy in the case of compounds $\mathrm{XIII}-\mathrm{XV}$. The two groups of substances have similar chemical structures, excepting the atomic group $-\mathrm{NH}$ added in the second group of structures.

For all studied molecules the ground state polarizability increases with the modulus of the computed molecular energy.

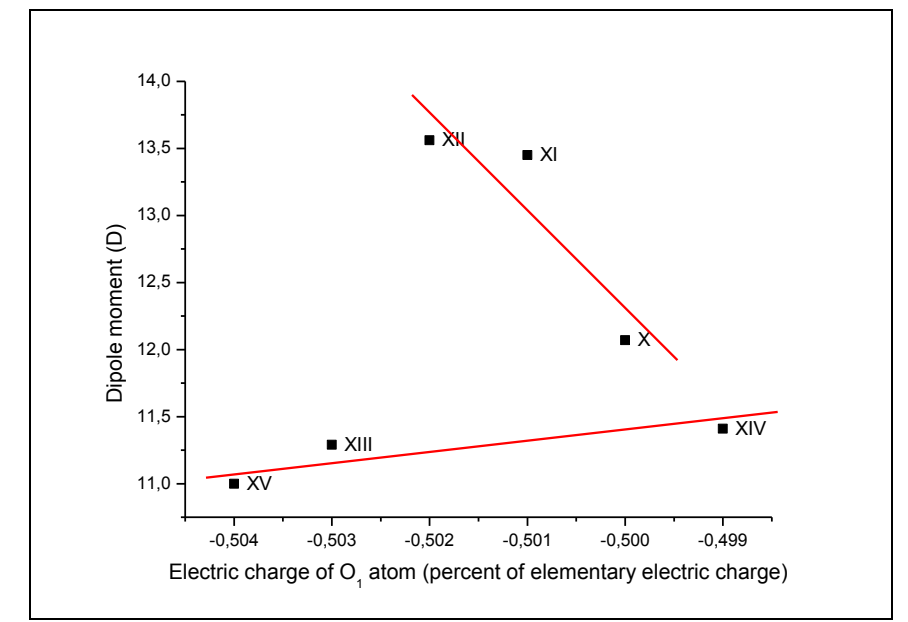

Figure 2. Dipole moment vs. electric charge near of oxygen atom from $\mathrm{NO}_{2}$ group

The increase in the electric dipole moment of the molecules from the group X - XII is induced by the decrease in the electronic charge near the first oxygen atom of $\mathrm{NO}_{2}$ atomic group. Contrarily, the same decrease determines the decrease in the dipole moment for the molecules belonging to the second group XIII - XV.

The electronic charges localized near the second oxygen atom of $\mathrm{NO}_{2}$ atomic group does not influence significantly the molecular dipole moment for the studied molecules. 


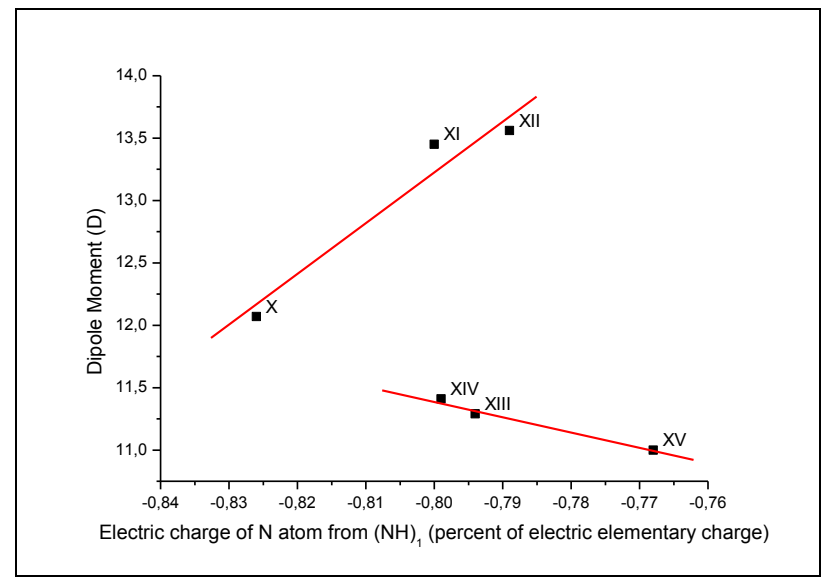

Figure 3. Dipole moment vs. electric charge near $\mathrm{N}$ of $\mathrm{NH}$ group

The electronic charge localized near nitrogen atom of $-\mathrm{NH}$ group influences the values of the electric dipole moment in the ground state of the studied molecules, by increasing it in the case of $\mathrm{X}$ XII group and decreasing it in the case of the group XIII - XV.

\section{Experimental part}

\section{1-(5'-nitroindazole-1'-yl-acetyl-4-aryl-thiosemicarbazides (I - III)}

Thiosemicarbazides (I - III) were synthesized in a solution of methyl alcohol by heating a mixture of 5-nitroindazol-1-yl acetic acid hydrazide with isothiocyanates: phenyl, p-tolyl and p-methoxyphenyl [5].

\section{5-mercapto-1,2,4-triazole-3,4-disubstituted (IV - VI)}

They were obtained by cyclizing 1,4-disubstituted acyl-thiosemicarbazides under the catalytic action of hydroxyl ions [5].

\section{3- [(5'-nitro-1H-indazole-1'-yl)-methyl]-4-aryl-1,2,4-triazole-5-thioacetic esters (VII-IX), General} procedure:

In a suspension of $0.01 \mathrm{~mol}$ of triazole in $150 \mathrm{~mL}$ of anhydrous ethanol was added $0.02 \mathrm{~mol}$ of sodium ethoxide and stirred for $10 \mathrm{~min}$. $0.01 \mathrm{~mol}$ of monobromoacetic acid ethyl ester was added, while stirring for $4 \mathrm{~h}$ at $65-70^{\circ} \mathrm{C}$. In the end of the reaction $200 \mathrm{~mL}$ of anhydrous benzene are added and stirring is continued, for $30 \mathrm{~min}$. The separated benzene layer is washed with a lot of distilled water in the separation funnel and then dried over anhydrous sodium sulphate. The benzene was distilled off under reduced pressure and the crude product precipitated out of the residue with anhydrous ethyl ether as crystals.

The final product is purified by recrystallization from ethyl alcohol.

\section{3-[(5'-nitro-1H-indazole-1'-yl)-methyl]-4-phenyl-1,2,4-triazole-5- $\alpha$-ethyl thioacetate (VII)}

White solid, (3.72 g; yield 85\%), m.p. $=203-205^{\circ} \mathrm{C}$.

Anal. calc. for $\mathrm{C}_{20} \mathrm{H}_{18} \mathrm{~N}_{6} \mathrm{O}_{4} \mathrm{~S}(\%)$ : C, 54.79; H, 4,10; N, 19.17; S, 7.30. Found (\%): C, 55.13; H, $4.37 ; \mathrm{N}, 19.58 ; \mathrm{S}, 7.59$.

FT-IR ( $\left.v, \mathrm{~cm}^{-1}\right): 1703$ (CO ester); $1328\left(\mathrm{NO}_{2}\right.$ sym.); $1598\left(\mathrm{NO}_{2}\right.$ asym. $) ; 1676(\mathrm{C}=\mathrm{N}) ; 1096(\mathrm{C}-\mathrm{N}-$ C); $690(\mathrm{C}-\mathrm{S}) ; 2933\left(\mathrm{CH}_{2}\right) ; 767,834$ (monosubstituted aromatic ring)

${ }^{1} \mathrm{H}-\mathrm{NMR}$ (DMSO-d $6,400 \mathrm{MHz}$ ), $\delta(\mathrm{ppm}): 1.21-1.29$ (t, 3H, $\left.\mathrm{CH}_{3}\right) ; 4.12-4.13\left(\mathrm{c}, 2 \mathrm{H}, \mathrm{CH}_{2}\right) ; 5.35$ (s, $2 \mathrm{H}, \mathrm{CH}_{2}$ ); 5.81 (s, 2H, $\mathrm{CH}_{2}$ ); 7.11-7.13 (d, 2H, CHAr); 7.37-7.39 (d, 2H, CHAr); 7.41-7.43 (t, 1H, CHAr); 7.84-7.89 (d, 1H, CHAr); 8.30 (s, 1H, CHAr); 8.49 (s, 1H, CHAr); 8.86-8.89 (d, 1H, CHAr). 
3-[(5'-nitro-1H-indazole-1'-yl)-methyl]-4-(p-tolyl)-1,2,4-triazole-5-a-ethyl thioacetate (VIII)

White solid, crystalline $(3.29 \mathrm{~g}$; yield $73 \%)$, m.p. $=210-212^{\circ} \mathrm{C}$.

Anal. calc. for $\mathrm{C}_{21} \mathrm{H}_{20} \mathrm{~N}_{6} \mathrm{O}_{4} \mathrm{~S}(\%)$ : C, 55.75; H, 4.42; N, 18.58; S, 7,07. Found (\%): C, 55.92; H, $4.69 ; \mathrm{N}, 18.89 ; \mathrm{S}, 7.39$.

FT-IR ( $\left.v, \mathrm{~cm}^{-1}\right): 1732$ (CO ester); $1312\left(\mathrm{NO}_{2}\right.$ sym.); $1530\left(\mathrm{NO}_{2}\right.$ asym. $) ; 1677(\mathrm{C}=\mathrm{N}) ; 1124(\mathrm{C}-\mathrm{N}-$ $\mathrm{C}) ; 586(\mathrm{C}-\mathrm{S}) ; 2936\left(\mathrm{CH}_{2}\right) ; 766,842$ (p-disubstituted benzene nucleus)

${ }^{1} \mathrm{H}-\mathrm{NMR}$ (DMSO-d $6,400 \mathrm{MHz}$ ), $\delta(\mathrm{ppm}): 1.20-1.22\left(\mathrm{t}, 3 \mathrm{H}, \mathrm{CH}_{3}\right) ; 2.34$ (s, 3H, $\mathrm{CH}_{3}$ ); 4.16-4.19 (c, $2 \mathrm{H}, \mathrm{CH}_{2}$ ); 5.70 (s, 2H, $\mathrm{CH}_{2}$ ); 5.81 (s, 2H, $\mathrm{CH}_{2}$ ); 7.14-7.16 (d, 2H, CHAr); 7.45-7.47 (d, 2H, CHAr); 7.81 (s, 1H, CHAr); 8.41-8.43 (d, 1H, CHAr); 8.56-8.58 (d, 1H, CHAr); 8.78 (s, 1H, CHAr).

3-[(5'-nitro-1H-indazole-1'-yl)-methyl]-4-(p-methoxyphenyl)-1,2,4-triazole-5- $\alpha$-ethyl thioacetate (IX)

White solid, crystalline $(3.32 \mathrm{~g}$; yield $71 \%)$, m.p. $=212-214^{\circ} \mathrm{C}$.

Anal. calc. for $\mathrm{C}_{21} \mathrm{H}_{20} \mathrm{~N}_{6} \mathrm{O}_{5} \mathrm{~S}(\%)$ : C, 53.84; H, 4,27; N, 17.94; S, 6.83. Found (\%): C, 54.06; H, 4.56; N, 18.28; S, 7.02.

FT-IR ( $\left.v, \mathrm{~cm}^{-1}\right): 1737(\mathrm{CO}$ ester $) ; 1337\left(\mathrm{NO}_{2}\right.$ sym. $) ; 1518\left(\mathrm{NO}_{2}\right.$ asym. $) ; 1623(\mathrm{C}=\mathrm{N}) ; 1065(\mathrm{C}-\mathrm{N}-$ C); $686(\mathrm{C}-\mathrm{S}) ; 2947\left(\mathrm{CH}_{2}\right) ; 749,766$ (p-disubstituted benzene nucleus).

${ }^{1} \mathrm{H}-\mathrm{NMR}$ (DMSO-d 6 , $\left.400 \mathrm{MHz}\right), \delta(\mathrm{ppm}): 1.19-1.21\left(\mathrm{t}, 3 \mathrm{H}, \mathrm{CH}_{3}\right) ; 3.84\left(\mathrm{~s}, 3 \mathrm{H}, \mathrm{OCH}_{3}\right) ; 4.08-4.11$ (c, 2H, $\left.\mathrm{CH}_{2}\right) ; 5.48$ (s, 2H, $\left.\mathrm{CH}_{2}\right) ; 5.77$ (s, 2H, $\left.\mathrm{CH}_{2}\right)$; 7.24-7.26 (d, 2H, CHAr); 7.54-7.57 (d, 2H, CHAr); 7.99 (s, 1H, CHAr); 8.29-8.31 (d, 1H, CHAr); 8.55-8.57 (d, 1H, CHAr); 8.65 (s, 1H, CHAr).

\section{Final compounds}

3-[(5'-nitro-1H-indazole-1'-yl)-methyl]-4-aryl-1,2,4-triazole-5-( $\alpha$-thioacetyl peptides (X-XV), General procedure:

In a suspension of $0.01 \mathrm{~mol}$ of ester (VII-IX) in $100 \mathrm{~mL}$ of anhydrous dioxane was added $0.02 \mathrm{~mol}$ of p-aminobenzoyl-D,L-phenylglycine or p-aminobenzoyl-D,L-phenylalanine respectively and warmed to $85-90^{\circ} \mathrm{C}$ for 5 hours.

From the reaction mixture a compound is precipitated with water after the cooling, a compound which, after purification by repeated recrystallization from acetone and anhydrous ethyl alcohol appears as white crystals.

\section{3-[(5'-nitro-1H-indazole-1'-yl)-methyl]-4-phenyl-1,2,4-triazole-5-( $\alpha$-thioacetyl p-aminobenzoyl]- D,L-phenylglycine $(X)$}

White solid, (5.75 g; yield 87\%), m.p. $=212-214^{\circ} \mathrm{C}$.

Anal. calc. for $\mathrm{C}_{33} \mathrm{H}_{26} \mathrm{~N}_{8} \mathrm{O}_{6} \mathrm{~S}(\%)$ : C, 59.81; H, 3.92; N, 16.91; S, 4.83. Found (\%): C, 60.18; H, $4.18 ; \mathrm{N}, 17.32 ; \mathrm{S}, 5.19$.

FT-IR $\left(v, \mathrm{~cm}^{-1}\right)$ : 2822, $2947(\mathrm{NH}) ; 1335\left(\mathrm{NO}_{2}\right.$ sym. $) ; 1573\left(\mathrm{NO}_{2}\right.$ asym. $) ; 1619(\mathrm{C}=\mathrm{N}) ; 1072(\mathrm{C}-\mathrm{N}-$ C); $688(\mathrm{C}-\mathrm{S}) ; 785\left(\mathrm{~S}-\mathrm{CH}_{2}\right) ; 1613$ (CO amide); 815, 897 (p-disubstituted benzene ring); 3242 $(\mathrm{COOH})$.

${ }^{1} \mathrm{H}-\mathrm{NMR}\left(\mathrm{DMSO}_{\mathrm{d}}, 400 \mathrm{MHz}\right), \delta(\mathrm{ppm}): 5.39\left(\mathrm{~s}, 2 \mathrm{H}, \mathrm{CH}_{2}\right) ; 5.56-5.57(\mathrm{~d}, 1 \mathrm{H}, \mathrm{CH}) ; 5.76(\mathrm{~s}, 2 \mathrm{H}$, $\mathrm{CH}_{2}$ ); 6.08-6.09 (d, 2H, CHAr); 6.91-6.93 (d, 2H, CHAr); 7.43-7.44 (m, 3H, CHAr); 7.45-7.46 (d, 2H, CHAr); 7.46-7.48 (t, 1H, CHAr); 7.48-7.48 (m, 2H, CHAr); 7.81-7.83 (d, 2H, CHAr); 7.99 (t, 1H, CHAr); 8.06 (s, 1H, NH); 8.27-8.29 (d, 1H, NH); 8.45 (s, 1H, CHAr); 8.57-8.59 (d, 1H, CHAr); 8.75 (s, 1H, CHAr); 12.66-12.68 (d, 1H, COOH) .

\section{3-[(5'-nitro-1H-indazole-1'-yl)-methyl]-4-(p-tolyl)-1,2,4-triazole-5-[( $\alpha$-thioacetyl p-aminobenzoyl $]$ -D,L-phenylglycine (XI) \\ White solid, (5.54 g; yield 82\%), m.p. $=218-220^{\circ} \mathrm{C}$. \\ Anal. calc. for $\mathrm{C}_{34} \mathrm{H}_{28} \mathrm{~N}_{8} \mathrm{O}_{6} \mathrm{~S}(\%)$ : C, 60.35; H, 4.14; N, 16.56; S, 4.73. Found (\%): C, 60.59; H, $4.45 ; \mathrm{N}, 16.95 ; \mathrm{S}, 5.12$.}


FT-IR (v, cm $\left.{ }^{-1}\right): 3309(\mathrm{NH}) ; 1339\left(\mathrm{NO}_{2}\right.$ sym. $) ; 1518\left(\mathrm{NO}_{2}\right.$ asym.); $1614(\mathrm{C}=\mathrm{N}) ; 1070(\mathrm{C}-\mathrm{N}-\mathrm{C})$; 688 (C-S); 790 (S- $\left.\mathrm{CH}_{2}\right) ; 1659$ (CO amide); 818 (p-disubstituted benzene nucleus); 3252 (COOH).

${ }^{1} \mathrm{H}-\mathrm{NMR}$ (DMSO-d $\left.6,400 \mathrm{MHz}\right), \delta(\mathrm{ppm}): 2.43\left(\mathrm{~s}, 3 \mathrm{H}, \mathrm{CH}_{3}\right) ; 5.51-5.53(\mathrm{~d}, 1 \mathrm{H}, \mathrm{CH}) ; 5.69$ (s, 2H, $\mathrm{CH}_{2}$ ); 5.83 (s, 2H, $\mathrm{CH}_{2}$ ); 6.57-6.59 (d, 2H, CHAr); 7.16-7.18 (d, 2H, CHAr); 7.25-7.27 (m, 3H, CHAr); 7.34-7.37 (d, 2H, CHAr); 7.40-7.42 (t, 1H, CHAr); 7.51-7.53 (m, 2H, CHAr); 7.70-7.73 (d, 2H, CHAr); 7.98 (s, 1H, NH); 8.38-8.41 (d, 1H, NH); 8.49 (s, 1H, CHAr); 8.61-8.63 (d, 1H, CHAr); 8.88 (s, 1H, CHAr); 12.72-12.74 (d, 1H, $\mathrm{COOH})$.

3-[(5'-nitro-1H-indazole-1'-yl)-methyl]-4-(p-methoxyphenyl)-1,2,4-triazole-5-[(a-thioacetyl paminobenzoyl]-D,L-phenylglycine (XII)

White solid, (5.46 g; yield 79\%), m.p. $=230-232^{\circ} \mathrm{C}$.

Anal. calc. for $\mathrm{C}_{34} \mathrm{H}_{28} \mathrm{~N}_{8} \mathrm{O}_{7} \mathrm{~S}(\%)$ : C, 58.95; H, 4.04; N, 16.18; S, 4.62. Found (\%): C, 59.14; H, $4.37 ; \mathrm{N}, 16.45 ; \mathrm{S}, 5.02$.

FT-IR (v, cm $\left.{ }^{-1}\right): 2959,3065(\mathrm{NH}) ; 1343\left(\mathrm{NO}_{2}\right.$ sym. $) ; 1521\left(\mathrm{NO}_{2}\right.$ asym. $) ; 1634(\mathrm{C}=\mathrm{N}) ; 1075(\mathrm{C}-\mathrm{N}-$ $\mathrm{C}) ; 1107\left(\mathrm{Ar}-\mathrm{OCH}_{3}\right) ; 703(\mathrm{C}-\mathrm{S}) ; 746\left(\mathrm{~S}-\mathrm{CH}_{2}\right) ; 1688$ (CO amide); 841, 872 (p-disubstituted benzene nucleus); $3282(\mathrm{COOH})$.

${ }^{1} \mathrm{H}-\mathrm{NMR}$ (DMSO-d $\left.6,400 \mathrm{MHz}\right), \delta(\mathrm{ppm}): 3.90\left(\mathrm{~s}, 3 \mathrm{H}, \mathrm{OCH}_{3}\right) ; 5.45-5.47(\mathrm{~d}, 1 \mathrm{H}, \mathrm{CH}) ; 5.62(\mathrm{~s}, 2 \mathrm{H}$, $\mathrm{CH}_{2}$ ); 5.77 (s, 2H, $\mathrm{CH}_{2}$ ); 6.89-6.92 (d, 2H, CHAr); 7.21-7.23 (d, 2H, CHAr); 7.29-7.32 (m, 3H, CHAr); 7.39-7.41 (d, 2H, CHAr); 7.44-7.46 (t, 1H, CHAr); 7.56-7.58 (m, 2H, CHAr); 7.71-7.73 (d, 2H, CHAr); 7.80 (s, 1H, NH); 8.20-8.23 (d, 1H, NH); 8.69 (s, 1H, CHAr); 8.74-8.76 (d, 1H, CHAr); 8.80 (s, 1H, CHAr); 12.69-12.71 (d, 1H, COOH).

3-[(5'-nitro-1H-indazole-1'-yl)-methyl]-4-phenyl-1,2,4-triazole-5-( $\alpha$-thioacetyl aminobenzoyl]-Lphenylalanine (XIII)

White solid, (5.62 g; yield 84\%), m.p. $=215-216^{\circ} \mathrm{C}$.

Anal. calc. for $\mathrm{C}_{34} \mathrm{H}_{28} \mathrm{~N}_{8} \mathrm{O}_{6} \mathrm{~S}(\%)$ : C, 60.35; H, 4.14; N, 16.56; S, 4.73. Found (\%): C, 60.73; H, $4.43 ; \mathrm{N}, 16.92 ; \mathrm{S}, 5.08$.

FT-IR (v, cm $\left.{ }^{-1}\right)$ : 3093, $3309(\mathrm{NH}) ; 1339\left(\mathrm{NO}_{2}\right.$ sym. $) ; 1518\left(\mathrm{NO}_{2}\right.$ asym. $) ; 1614(\mathrm{C}=\mathrm{N}) ; 1070(\mathrm{C}-\mathrm{N}-$ C); $688(\mathrm{C}-\mathrm{S}) ; 790\left(\mathrm{~S}-\mathrm{CH}_{2}\right) ; 1659$ (CO amide); 818 (p-disubstituted benzene nucleus); $3252(\mathrm{COOH})$.

${ }^{1} \mathrm{H}-\mathrm{NMR}$ (DMSO-d $6,400 \mathrm{MHz}$ ), $\delta$ (ppm): 2.9-3.2 (m, 2H, $\left.\mathrm{CH}_{2}\right) ; 4.5-4.6$ (m, 1H, CH); 5.63 (s, 2H, $\mathrm{CH}_{2}$ ); 5.97 (s, 2H, $\mathrm{CH}_{2}$ ); 6.5-6.52 (d, 2H, CHAr); 7.15-7.18 (t, 1H, CHAr); 7.23-7.25 (m, 4H, CHAr); 7.52-7.54 (d, 2H, CHAr); 7.70 (t, 1H, CHAr); 7.86-7.88 (d, 2H, CHAr); 7.90-7.92 (d, 2H, CHAr); 8.15-8.17 (d, 1H, NH); 8.26 (s, 1H, CHAr); 8.39-8.42 (d, 1H, CHAr); 8.56-8.58 (d, 1H, CHAr); 8.708.74 (d, 1H, NH); 8.89 (s, 1H, CHAr); 12.5-12.9 (m, 1H, COOH).

3-[(5'-nitro-1H-indazole-1'-yl)-methyl]-4-(p-tolyl)-1,2,4-triazole-5-[( $\alpha$-thioacetyl-aminobenzoyl]L-phenylalanine (XIV)

White solid, crystalline $(5.52 \mathrm{~g}$; yield $80 \%)$, m.p. $=225-226^{\circ} \mathrm{C}$.

Anal. calc. for $\mathrm{C}_{35} \mathrm{H}_{30} \mathrm{~N}_{8} \mathrm{O}_{6} \mathrm{~S}(\%)$ : C, 60.85; H, 4.34; N, 16.23; S, 4.63. Found (\%): C, 61.08; H, $4.51 ; \mathrm{N}, 16.57 ; \mathrm{S}, 5.03$.

FT-IR $\left(v, \mathrm{~cm}^{-1}\right): 3408(\mathrm{NH}) ; 1338\left(\mathrm{NO}_{2}\right.$ sym. $) ; 1582\left(\mathrm{NO}_{2}\right.$ asym.); $1617(\mathrm{C}=\mathrm{N}) ; 1067(\mathrm{C}-\mathrm{N}-\mathrm{C})$; $668(\mathrm{C}-\mathrm{S}) ; 750$ (S- $\left.\mathrm{CH}_{2}\right) ; 1653$ (CO amide); 880 (p-disubstituted benzene nucleus); $3268(\mathrm{COOH})$.

${ }^{1} \mathrm{H}-\mathrm{NMR}\left(\mathrm{DMSO}_{\mathrm{d}}, 400 \mathrm{MHz}\right), \delta(\mathrm{ppm}): 2.11\left(\mathrm{~s}, 3 \mathrm{H}, \mathrm{CH}_{3}\right) ; 3.10-3.30\left(\mathrm{~m}, 2 \mathrm{H}, \mathrm{CH}_{2}\right) ; 4.99-5.06$ (m, 1H, CH); 5.30 (s, 2H, CH 2$)$; 5.65 (s, 2H, $\mathrm{CH}_{2}$ ); 6.3-6.6 (d, 2H, CHAr); 7.06-7.09 (t, 1H, CHAr); 7.19-7.22 (m, 4H, CHAr); 7.40-7.46 (d, 2H, CHAr); 7.64 (t, 1H, CHAr); 7.72-7.79 (d, 2H, CHAr); 7.92-7.99 (d, 2H, CHAr); 8.23-8.25 (d, 1H, NH); 8.39 (s, 1H, CHAr); 8.60-8.65 (d, 1H, CHAr); 8.698.72 (d, 1H, NH); 8.93 (s, 1H, CHAr); 12.21-12.40 (m, 1H, COOH). 


\section{3-[(5'-nitro-1H-indazole-1'-yl)-methyl]-4-(p-methoxyphenyl)-1,2,4-triazole-5-[( $\alpha$-thioacetyl p-} aminobenzoyl]-L-phenylalanine (XV)

White powder, (5.50 g; yield 78\%), m.p. $=234-235^{\circ} \mathrm{C}$, in decomposition.

Anal. calc. for $\mathrm{C}_{35} \mathrm{H}_{30} \mathrm{~N}_{8} \mathrm{O}_{7} \mathrm{~S}(\%)$ : C, 59.49; H, 4.24; N, 15.86; S, 4.53. Found (\%): C, 59.80; H, $4.51 ; \mathrm{N}, 16.24 ; \mathrm{S}, 4.86$.

FT-IR $\left(v, \mathrm{~cm}^{-1}\right): 2850,3000(\mathrm{NH}) ; 1342\left(\mathrm{NO}_{2} \mathrm{sym}.\right) ; 1516\left(\mathrm{NO}_{2}\right.$ asym. $) ; 1616(\mathrm{C}=\mathrm{N}) ; 1069(\mathrm{C}-\mathrm{N}-$ C ); $1109\left(\mathrm{OCH}_{3}\right) ; 708(\mathrm{C}-\mathrm{S}) ; 752\left(\mathrm{~S}-\mathrm{CH}_{2}\right) ; 1681$ (CO amide); 803, 821 (p-disubstituted benzene nucleus); $3286(\mathrm{COOH})$.

${ }^{1} \mathrm{H}-\mathrm{NMR}$ (DMSO-d $\left.6,400 \mathrm{MHz}\right), \delta(\mathrm{ppm}): 2.87-2.92\left(\mathrm{~m}, 2 \mathrm{H}, \mathrm{CH}_{2}\right) ; 3.94$ (s, 3H, $\left.\mathrm{OCH}_{3}\right) ; 4.68-4.71$ (m, 1H, CH); 5.51 (s, 2H, $\left.\mathrm{CH}_{2}\right) ; 5.80\left(\mathrm{~s}, 2 \mathrm{H}, \mathrm{CH}_{2}\right) ; 6.36-6.44$ (d, 2H, CHAr); 7.26-7.28 (t, 1H, CHAr); 7.34-7.41 (m, 4H, CHAr); 7.49-7.52 (d, 2H, CHAr); 7.79 (t, 1H, CHAr); 7.89-7.93 (d, 2H, CHAr); 7.96-7.99 (d, 2H, CHAr); 8.19-8.23 (d, 1H, NH); 8.39 (s, 1H, CHAr); 8.48-8.51 (d, 1H, CHAr); 8.828.87 (d, 1H, NH); 8.95 (s, 1H, CHAr); 12.87-12.95 (m, 1H, COOH).

\section{Conclusions}

- There was synthesised the compounds VII-XV new, not mentioned in the specialized literature;

- The 3- [(5'-nitro-1H-indazole-1'-yl)-methyl]-4-aryl-1,2,4-triazole-5-thioacetic esters (VII-IX) were prepared by reaction between 5-mercapto-1,2,4-triazole-3,4-disubstituted (IV - VI) and monobromoacetic acid ethyl ester, in alkaline medium;

- The synthesis for 3-[(5'-nitro-1H-indazole-1'-yl)-methyl]-4-aryl-1,2,4-triazole-5-( $\alpha$-thioacetyl peptides (X-XV) was performed by grafting the p-aminobenzoyl-D,L-phenylglycine and paminobenzoyl-D,L-phenylalanine respectively, on the triazole nucleus from the esters (VII-IX), following a possible biological activity of them, well known being the importance shown by the amide fragments from many substances

- The structure of all compounds was confirmed by elemental and spectral analysis (FT-IR, ${ }^{1} \mathrm{H}-$ NMR).

\section{References}

1. NASTASA, V., SUNEL, V., BUDEANU, C. H., RUSAN, M., DRAGOMIR, B., Rev. Med. Chir. Soc. Med. Nat., Iasi, 81, 1977, p. 463.

2. SUNEL, V., LIONTE, C., BASU, C., CHEPTEA, C., Indian J. Chem., 2, 2005, p. 1.

3. GREBINISAN, D., HOLBAN, M., SUNEL, V., POPA, M., DESBRIERES, J., LIONTE, C., Cell. Chem. Technol., 45, 2011, p. 571.

4. SUNEL, V., POPA, M., DESBRIERES, J., PROFIRE, L., PINTILIE, O., LIONTE, C., Molecules, 13, 2008, p.177.

5. SUNEL, V., BASU, C., CIUGUREANU, C., GRADINARU, R., An. Șt. Univ. "Al. I. Cuza” Iași, S. I c, 7, 1999, p. 335.

6. ONNIS, V., COCCO, M. T., LILliU, V., CONGIU, C., Bioorg. Med. Chem., 16 (5), 2008, p. 2367.

7. CHIACCHIO, U., BARBERA, V., BONFANTI, R., BROGGINI, G. L., CAMPISI, A., GAZZOLA, S., PARENTI, R., ROMEO, G., Bioorg. Med. Chem., 21 (18), 2013, p. 5748.

8. ZHAO, L., DING, H., ZHAO, B., LU, C., YAO, Y., Polyhedron, 83, 2014, p. 50.

9. MIGUELEZ, J., BOTO, A., MARIN, R., DIAZ, M., Eur. J. Med. Chem., 66, 2013, p. 540.

10. Li, L., Wang, H., JIN, C., CHEN, M., JIANG, S., CHENG, J., JIANG, S., Int. J. Biol. Macromol., 123, 2019, p.133.

11. RUDDARRAJU, R. R., MURUGUlla, A. C., KOTlA, R., TIRUMALASETTY, M.C.B., PARASA, L.S., Eur. J. Med. Chem., 123, 2016, p. 379.

12. PETROVA, K.T., POTEWAR, T.M., CORREIA-DA-SILVA, P., BARROS, M.T., FERREIRA, I.C.F.R., 417, 2016, p. 379.

13. SINGH, R.J., SING, K.D., Eur. J. Chem., 7, 2010, p. 37. 
14. PADMAVATHI, V., SUDHAKAR, G., PADMAJA, A., KONODAIAH, P., SHAZIA, A., Eur. J. Med. Chem., 44, 2009, p. 2016.

15. MOISE, M., ȘUNEL, V., PROFIRE, L., POPA, M., DESBRIERES, J., Peptu, C., Molecules, 14, 2009, p. 1621.

16. OMAR, M., ABDULLAH, S.E., SHEHTA, I.A., HALBIB, E., Molecules, 15, 2010, p. 2526.

17. XU, J., CAO, Y., ZHANG, J., YU, S., ZOU, Y., CHAI, X., WU, Q., ZHANG, D., JANG, Y., SUN, Q., Eur. J. Med. Chem., 46, 2011, p. 3142.

18. DING, Z., NI, T., XIE, F., HAO, Y., YU, S., CHAI, X., JIN, Y., WANG, T., JIANG, Y., ZHANG, D., Bioorg. Med. Chem. Lett., 30, 2020, p. 126.

19. ZITOUNI, G., KAPLANCIKLI, Z.A., YTLDIZ, M.T., CHEVALLET, P., KAYA, D., Eur. J. Med. Chem., 40, 2005, p. 607.

20. GILONI, S.J., KHAN, S.A., SIDDIQUI, N., Bioorg. Med. Chem. Lett., 20, 2010, p. 4762.

21. AMIR, M., KUMAR, H., JAVED, S.A., Eur. J. Med. Chem., 43, 2008, p. 2056.

22. KARROUCHI, K., CHEMLAL, L., TAOUFIK, J., CHERRAH, Y., ANSAR, Y.M., Ann. Pharm. Fr., 74 (6), 2016, p. 431.

23. GRESSIER, D., PROVILLAC, C., HERNANDEZ, P., AMOURETTE, C., DISERBO, M., LION, C., RIMA, G., Bioorg. Med. Chem., 17, 2009, p. 5275.

24. CONROW, R., DELGADO, P., DEAN, W.D., CALLEN, G.R., PLUMMER, S.V., Tetrahedron Lett., 49, 2008, p. 2348.

25. GUDMUNDSON, K.S., TIDWELL, J., LIPPA, N., J. Med. Chem., 43, 2000, p. 2464.

26. RODRIGUEZ, J., GERPE, A., AGUIRRE, G., KEMMERLING, U., PIRO, O. E., ARAN, V. J., MAYA, J. D., GONZALEZ, M., CERECETTO, H., Eur. J. Med. Chem., 44, 2009, p. 1545.

27. CHEPTEA, C., SUNEL, V., DESBRIERES, J., POPA, M., J. Heterocycl. Chem., 50, 2013, p. 366.

28. CARON, S., VAZQUEZ, E., Org. Process Res. Dev., 5, 2001, p. 587.

29. CHEPTEA, C., DULCESCU, M. M., DOROHOI, D. O., SUNEL, V., DESBRIERES, J., Dig. J. Nanomater. Bios., 7, 2012, p. 287.

30. MAGGIO, B., RAIMONDI, M.V., RAFFA, D., PLESCIA, F., CASCIOFERRO, S., PLESCIA, S., TOLOMEO, M., CRISTINA, A., PIPITONE, R.M., GRIMAUDO, S., DAIDONE, G., Eur. J. Med. Chem., 46, 2011, p. 168.

31. CHEPTEA, C., SUNEL, V., STAN, C., DOROHOI, D. O., Rev. Roum. Chim., București, 57 (2), 2012, p. 229.

32. CHEPTEA, C., SunEl, V., HOlBAn, M., DeSbrieres, J., POPA, M., LiONTE, C., Cell. Chem. Technol., 46, 2012, p. 19.

33. SUN, J.H., TELEHA, A.C., YAN, S.J., RODGERS, D.J., NUGIEL, A.D., J. Org. Chem., 62, 1997, p. 5627.

34. BOUILLON, I., ZAJICEK, J., PUDELOVA, N., KRCHNAK, V., J. Org. Chem., 21, 2008, p. 9027.

35. BAI, M., CARR, G., ORAZIO, R., FRIEDERCH, T. D., DOBRITSA, S., FITZPATRIK, K., GUZZO, R.P., KITCHEN, D.B., LYNCH, A.M., PEACE, D., SAJAD, M., USYATINSKY, A., Wolf, A.M., Bioorg. Med. Chem. Lett., 20, 2010, p. 3017.

36. CHOU, S., SHAO, C., WANG, J., SHAN, A., XU, L., DONG, N., SHORT, Z., Acta Biomater., 30, 2016, p. 78.

37. SUN, L., ZHENG, C., WEBSTER, T.J., Int. J. Nanomed., 12, 2017, p. 73.

38. TAILHADES, J., SIMPSON, N.M., SEPAROVIC, F., OTVOS, L., HOSSAIN, M.A., WADE, J.D., Amino Acids, 46, 2014, p. 2287.

39. ROISIER, J.P., LEON, M., OGILVIE, A., GOODYER, J., Neuropshychopharmacology, 30, 2005, p. 775.

40. LAURentani, F., MAgGiO, M., NARDElli, A., SACCAVINI M., LEDA, G., J. Amer. Geriat. Soc., 56, 2008, p. 1977. 
41. BREIVIK, T., GUNDERSEN, Y., VAAGENES, P., FONNUM, F., OPSTAD, P.K., J. Periodont. Res., 40, 2005, p. 43.

42. LI, L., WANG, A., JIN, C., CHEN, M., JIANG, S., CHENG, J., JIANG, SH., Int. J. Biol. Macromol., 123, 2019, p. 133.

43. MONTEIRO, L.S., MARTINS, P., OLIVEIRA, S., MACHADO, I., COSTA, M., Bioorg. Chem., 89, 2019, p. 102983.

44. TRIPATHI, A.K., KUMARI, T., TANDON, A., SAYEED, M., AFSHAN, T., KATHURIA, M., SHUKLA, P.K., MITRA, K., GHOSH, J., Acta Biomater., 57, 2017, p. 170.

45. JĘDRZEJCZAK, K., HRYNCZYSZYN, P., SZCZESIO, M., ARTYM, J., KOLESIŃSKA, B., Bioorg. Med. Chem., 25, (16), 2017, p. 4265.

46. PATEL, T. S., BHATT, J. D., DIXIT, R. B., CHUDASAMA, C. J., DIXIT, B. C., Bioorg. Med. Chem., 27 (16), 2019, p. 3574.

47. SEYDEL, J.K., BUTTE, W., J. Med. Chem., 20, 1977, p. 439.

48. MOISE, M., SUNEL, V., PROFIRE, L., DESBRIERES, J., PEPTU, C., Bul. Inst. Polit., Iasi, S. IIc, 55 (59), 2000, p. 55.

49. MOISE, M., SUNEL, V., PROFIRE, L., POPA, M., LIONTE, C., Farmacia, 16, 2008, p. 283.

50. RUSSO, F., GHERALDONI, M., Boll. Chim. Farm., 108, 1969, p. 128.

51. CHEPTEA, C., SUNEL, V., MANAHEDJI ARDESHIR, S., MOROSANU, A.C., DOROHOI, D.O., Mol. Cryst. Liq. Cryst., accepted 2020.

Manuscript received: 18.12 .2019 